\title{
Assessment of Calcimetric and Titrimetric Methods for Calcium Carbonate Estimation of Five Soil Types in Central Sudan
}

\author{
Jamal T. Elfaki', Mohamed O. Gafer², Magboul M. Sulieman ${ }^{3 *}$, Mushtaha E. Ali' \\ ${ }^{1}$ Department of Seeds Technology, Nile Valley University, Atbara, Sudan \\ ${ }^{2}$ Soil and Water science Department, College of Agricultural Studies, Sudan University of Science and \\ Technology, Khartoum, Sudan \\ ${ }^{3}$ Department of Soil and Environment Sciences, University of Khartoum, Khartoum, Sudan \\ ${ }^{4}$ General Administration of Natural Resource and Sustainable Development, Khartoum, Sudan \\ Email: *magboul@uofk.edu
}

Received 27 December 2015; accepted 19 January 2016; published 22 January 2016

Copyright (C) 2016 by authors and Scientific Research Publishing Inc.

This work is licensed under the Creative Commons Attribution International License (CC BY). http://creativecommons.org/licenses/by/4.0/

(c) (i) Open Access

\begin{abstract}
Despite the $\mathrm{CaCO}_{3}$ estimation using titration method was not reliable, but up to the present time, some soil laboratories in Sudan still used this method. The objective of this study was to compare and assess the results of calcimetric and titrimetric methods of quantitative estimation for soil calcium carbonate of different soils in Sudan. 26 soil samples from five soil profiles were collected from different climatological and ecological regions in central Sudan. $\mathrm{CaCO}_{3}$ equivalent was estimated using calcimeter and titration methods in order to find accurate, rapid and suitable method for soils of Sudan. The results revealed that there are no significant differences between calcimeter and titration methods for calcium carbonate estimation in all studied samples except in samples from Gedaref area. We concluded that when the Calcimeter method used for $\mathrm{CaCO}_{3}$ estimation, the differences between one person and another in detecting titration end point would be avoided, rapid and accurate results would be obtained compared to titration method. Additionally, time would be saved; fewer amounts of chemicals would be used. From this study, we highly recommend using calcimeter method for $\mathrm{CaCO}_{3}$ estimation for soils of Sudan.
\end{abstract}

\section{Keywords}

Ecological Regions, Central Sudan, Calcimeter, Titration Method

\footnotetext{
${ }^{*}$ Corresponding author.
}

How to cite this paper: Elfaki, J.T., Gafer, M.O., Sulieman, M.M. and Ali, M.E. (2016) Assessment of Calcimetric and Titrimetric Methods for Calcium Carbonate Estimation of Five Soil Types in Central Sudan. Journal of Geoscience and Environment Protection, 4, 120-127. http://dx.doi.org/10.4236/gep.2016.41014 


\section{Introduction}

The major soils in Sudan can be divided geographically into three categories: the sandy soils of the northern and west central regions, the clay soils of the central and eastern regions, and the laterite soils of the southern regions [1] (Elfaki et al., 2015).

Carbonate is a natural constituent of many soils in the world; most carbonate minerals found in soils of arid regions of Sudan are calcite $\left(\mathrm{CaCO}_{3}\right)$ and dolomite $\left(\mathrm{Ca} \mathrm{Mg}, \mathrm{CO}_{3}\right)$ minerals and exist mainly in the soils of the northern Sudan [2] (Ibrahim, 2008).

Most agricultural and environmental planning requires soil analysis, or at least should require analysis for better implementation for any change. Furthermore, better practical analysis methods can rapidly estimate soil properties needed to improve quantitative assessments of land management problems [3] (Shepherd and Walsh, 2002).

Calcium and magnesium carbonate occur naturally in some soils and sediments notably on calcareous soils and sediments notably on calcareous lithologies, and where the shell fragments are present, their presence may also be the result of human activity. Naturally, occurring carbonate such as limestone, dolomite and shell will also contribute to the total carbonate of the soil and their potential presence should be considered when interpreting the data. Carbonates may also be precipitated from the ground water in hard water areas [4] (El Mahi et al., 1987).

Calcium carbonate concentration is determined by dissolution of carbonate is on excess of $1 \mathrm{~N} \mathrm{HCl}$, followed by back titration of the remaining acid using $1 \mathrm{~N} \mathrm{NaOH}$. This method is used for carbonate analysis in the soil and composed of two-phase analysis.

1) The soil is mixed with a known amount of hydrochloric acid ( $\mathrm{HCl})$ using the dissolution of calcium carbonate $\mathrm{CaCO}_{3}$ and creating calcium chloride $\left(\mathrm{CaCl}_{2}\right)$, water and carbon dioxide.

$$
\mathrm{CaCO}_{3}+2 \mathrm{HCl} \rightarrow \mathrm{CaCl}_{2}+\mathrm{H}_{2} \mathrm{O}+\mathrm{CO}_{2}
$$

2) The amount of acid left is measured by titrating it with sodium hydroxide $(\mathrm{NaOH})$ to produce sodium chloride $(\mathrm{NaCl})$ and water, adding phenolphthalein indicator to the solution causes it to turn pink when all the acid have reacted [5] (Rowell, 1994).

$$
\mathrm{HCl}+\mathrm{NaOH} \rightarrow \mathrm{NaCl}+\mathrm{H}_{2} \mathrm{O}
$$

[6] Loeppert and Suarez (1996) reported that;a pressure calcimeter method was used to determine the carbonate content to form $\mathrm{CO}_{2}$ at constant temperature. The increase in pressure is linearly related to the quantity of carbonate present in the sample. While Crowther (2006) mentioned that calcimeter method should be used when the concentration of carbonate is expected to be low. In addition, [7] Hodgson (1974) considered calcimeter semi-quantitative estimate of carbonate content in soil by observing the reaction when $10 \% \mathrm{HCl}$ added to the soil.

Calcimeter instrument is used to estimate carbon dioxide $\left(\mathrm{CO}_{2}\right)$ volume obtained from the reaction between soil carbonate with hydrochloric acid $(\mathrm{HCl})$ at room temperature and atmospheric pressure. The volume of gas should be corrected to standard temperature and pressure, and these amounts of carbonate can be calculated according to the statement; one mole of gas occupies 22.41 liter at standard temperature and pressure [8] (Balázs et al., 2005).

Despite, the $\mathrm{CaCO}_{3}$ estimation using titration method is not reliable as mentioned by many researchers, but up to the present time, some soil laboratories in Sudan still use this method. Therefore, the aim of this study is to compare and assess the results of $\mathrm{CaCO}_{3}$ obtained by using calcimeter and titration methods in order to identify the most accuracy method as well as most suitable to be used for soils of Sudan.

\section{Materials and Methods}

\subsection{Soil Sampling and Characterization}

26 soil samples from five soil profiles were collected from different climatological and ecological regions in central Sudan, which included; Gedaref area, Khartoum area, Wad Madani area and Khartoum North area (recent Nile terrace). Each soil profile was studied in the field, and described following the format of the [9] FAO (2006), guidelines of soil profile description and sampled according to diagnostic or genetic horizons and classified following the American system for soil classification [10] (Soil survey staff, 2014a). 
Each sample was placed in a cloth bag, labeled with; collected data, area, soil profile number, sample depth, then, subjected to physical and chemical analyses at the soil laboratories in Khartoum University. Soil pH was determined on the saturated paste using digital pH meter model (3510, Jenway) according to [11] (Blakemore et al., 1987), and the electrical conductivity of the saturation extraction was used as a measure of soil salinity according to [12] (Rhoades, 1990). The organic matter (OM) was determined used Walkley-Black method [13] (Chapman and Pratt, 1961).

Soil texture was determined using particle size analyzer model (Mastersizer 2000, Malvern) and textural classes were obtained using USDA textural Triangle according [14] (Soil Survey Staff, 2014b). Soil phosphorus was analyzed using spectrophotometer model (Lambda EZ 150, PerkinElmer, USA) according to [15] (Olsen and Sommers, 1982).

\subsection{Calcimeter Method for $\% \mathrm{CaCO}_{3}$ Estimation}

Percent calcium carbonate $\left(\% \mathrm{CaCO}_{3}\right)$ was estimated by Calcimeter: $2 \mathrm{~g}$ of soil sample was treated by $0.1 \mathrm{~N}$ $\mathrm{HCL}$; the volume of $\mathrm{CO}_{2}$ from pure calcium carbonate and samples were recorded. Then, the percent calcium carbonate was calculated according to [8] (Balázs et al., 2005).

\subsection{Titration Method for $\% \mathrm{CaCO}_{3}$ Estimation}

$5 \mathrm{~g}$ of fine crushed soil sample was placed into conical flask, $10 \mathrm{ml}$ of $1 \mathrm{~N} \mathrm{HCl}$ and $50 \mathrm{ml}$ distilled water were added, heated until boiling for 2 mins. Then, left until cool and 3 drops of phenolphthalein indicator was added and titrated against $1 \mathrm{~N} \mathrm{NaOH}$. Then, the percent calcium carbonate was calculated according to [8] (Balázs et al., 2005).

\subsection{Statistical Analysis}

Statistical differences between samples were determined using statistical analysis according to [16] (Snedecor, 1965), using T-test with multiple samples where differences were calculated from various measurements. The means of these differences were obtained $(\bar{D})$, the deviation from each measurement was used to obtain the standard deviation $\left(s_{d}\right)$. Then the T value was calculated from the equation below:

$$
T=\frac{\bar{D}}{S_{d}} \sqrt{N}
$$

where:

$T \equiv$ Calculated T value

$\bar{D} \equiv$ Means of differences.

$s_{d} \equiv$ Standard deviation.

$\mathrm{N} \equiv$ Number of samples

\section{Results and Discussion}

\subsection{Morphological Properties}

The description of the study sites and selected morphological properties of representative soil profiles are presented in Table 1 and Table 2, respectively. The parent material of Profiles I and II was alluvium/colluvium and old alluvium of the Bule Nile, respectively. While the parent material of profiles III, V, and VI were alluvium. Soil texture of all profiles belong to five textural classes; loam, sandy clay loam, clay loam silty clay and clay. All profiles showed angular/sub-angular blocky structure in the surface horizon and the lower horizons were massive. The quantity of roots in the soil profiles decreased with depth and the boundary between horizons was generally diffused and smooth.

\subsection{Physical and Chemical Properties}

Some of the physical and chemical properties of the representative profiles were presented in Table 3. Gadarif area soil was non-saline, non-sodic and calcareous, while Soba area soil at Khartoum state was saline-sodic and calcareous. The soil of Agricultural Research Corporation Farm, Gezira State is non-saline at the depth of 0 - 84 
Table 1. Selected site properties of the studied profiles.

\begin{tabular}{|c|c|c|c|c|c|c|}
\hline \multirow{2}{*}{$\begin{array}{c}\text { Profile } \\
\text { No. }\end{array}$} & \multirow{2}{*}{ Location } & \multicolumn{2}{|c|}{ Coordinates } & \multirow{2}{*}{ Parent Material } & \multirow{2}{*}{ Slope (\%) } & \multirow{2}{*}{ Land Use } \\
\hline & & Latitude & Longitude & & & \\
\hline P1 & Gedaref & $14^{\circ} 01^{\prime \prime}$ & $35^{\circ} 23^{\prime \prime}$ & Alluvium/Colluvium & Flat & Agric. \\
\hline P2 & Soba & $15^{\circ} 30^{\prime \prime}$ & $32^{\circ} 37^{\prime \prime}$ & Old alluvium of the Blue Nile & Flat & Forest \\
\hline P3 & Wad Madani & $14^{\circ} 23^{\prime \prime}$ & $33^{\circ} 29^{\prime \prime}$ & Alluvium & Flat & Agric. \\
\hline $\mathbf{P 4}$ & Recent Nile terrace & $15^{\circ} 39^{\prime \prime}$ & $32^{\circ} 31^{\prime \prime}$ & Alluvium & Flat & Agric \\
\hline P5 & College Farm & $15^{\circ} 39^{\prime \prime}$ & $32^{\circ} 31^{\prime \prime}$ & Alluvium & Flat & Agric. \\
\hline
\end{tabular}

Table 2. Selected morphological properties of the representative profiles.

\begin{tabular}{|c|c|c|c|c|c|c|c|}
\hline $\begin{array}{l}\text { Profile } \\
\text { No. }\end{array}$ & $\begin{array}{l}\text { Depth } \\
\text { (cm) }\end{array}$ & $\begin{array}{l}\text { Color } \\
\text { (moist) }\end{array}$ & $\begin{array}{l}\text { Texture } \\
\text { (field) }\end{array}$ & Structure $^{\mathrm{b}}$ & Roots $^{c}$ & Boundary $^{d}$ & Diagnostic characteristics \\
\hline \multirow{5}{*}{$\mathrm{P} 1$} & $0-18$ & $2.5 Y 3 / 2$ & $\mathrm{C}$ & 2fabk & $1 \mathrm{f}$ & $\mathrm{cw}$ & Cracks up to $4 \mathrm{~cm}$ \\
\hline & 18 - 48 & $2.5 Y 3 / 2$ & C & 1fabk & $1 \mathrm{f}$ & cW & Cracks at the base of the horizon \\
\hline & $48-80$ & $2.5 Y 3 / 2$ & $\mathrm{C}$ & 1 fsbk & $1 \mathrm{f}$ & $\mathrm{cW}$ & Cracks up to $3 \mathrm{~cm}$ \\
\hline & $80-105$ & 10YR 6/3 & $\mathrm{C}$ & ma & $1 \mathrm{f}$ & $\mathrm{cW}$ & Slickensides not clearly visible \\
\hline & $105-150$ & 10YR 6/3 & $\mathrm{C}$ & $2 \mathrm{csbk}$ & $1 \mathrm{f}$ & $\mathrm{cW}$ & - \\
\hline \multirow{5}{*}{ P2 } & $0-30$ & 7.5YR 4/4 & $\mathrm{L}$ & ma & $2 \mathrm{f}$ & CS & - \\
\hline & $30-45$ & $10 Y R 4 / 4$ & $\mathrm{Cl}$ & $1 \mathrm{msbk}$ & $2 f$ & is & - \\
\hline & $45-107$ & $10 Y R \quad 4 / 3$ & $\mathrm{C}$ & 2abk & $2 \mathrm{f}$ & ds & - \\
\hline & $107-150$ & 10YR 5/6 & $\mathrm{C}$ & $2 \mathrm{sbk}$ & - & ds & Slightly cemented \\
\hline & $0-27$ & $2.5 Y R 3 / 2$ & $\mathrm{Cl}$ & $2 \mathrm{fabk}$ & $1 \mathrm{f}$ & $\mathrm{cw}$ & Cracks up to $4 \mathrm{~cm}$ \\
\hline \multirow{4}{*}{ P3 } & $27-56$ & $2.5 \mathrm{YR} 3 / 2$ & C & 1 fabk & $2 \mathrm{f}$ & $\mathrm{cw}$ & Cracks at the base of horizon \\
\hline & $56-84$ & $2.5 Y R 3 / 2$ & $\mathrm{C}$ & $1 \mathrm{cabk}$ & $1 \mathrm{f}$ & iw & Cracks up to $2 \mathrm{~cm}$ \\
\hline & $84-130$ & 10YR 6/3 & $\mathrm{C}$ & ma & 1f & $\mathrm{cw}$ & - \\
\hline & $130-150$ & 10YR 6/3 & C & 2csbk & $2 f$ & $\mathrm{cw}$ & - \\
\hline \multirow{6}{*}{ P4 } & $0-12$ & 10YR 3/3 & $\mathrm{C}$ & $3 f g$ & $4 \mathrm{f}$ & CS & - \\
\hline & $12-48$ & $10 Y R 3 / 3$ & Scl & 1csbk & $4 \mathrm{vf}$ & $\mathrm{cW}$ & - \\
\hline & $48-68$ & 10YR 3/2 & Scl & 2abk & $3 v f$ & $\mathrm{cw}$ & Common krotovina \\
\hline & $68-86$ & 10YR 3/3 & Scl & ma & $3 \mathrm{vf}$ & aw & - \\
\hline & $86-111$ & 10YR 3/2 & Scl & ma & $3 \mathrm{vf}$ & $\mathrm{cw}$ & - \\
\hline & $111-150$ & 10YR 3/3 & Scl & ma & $3 \mathrm{vf}$ & $\mathrm{cw}$ & - \\
\hline \multirow{6}{*}{ P5 } & $0-12$ & 10YR 3/3 & $\mathrm{C}$ & $2 \mathrm{sbk}$ & $3 f$ & CS & Few cracks \\
\hline & $12-36$ & 10YR 4/3 & Sic & $1 \mathrm{msbk}$ & $1 \mathrm{vf}$ & CS & Few soft $\mathrm{CaCO}_{3}$ aggregates \\
\hline & $36-57$ & 10YR 3/3 & $\mathrm{C}$ & 1mabk & $1 \mathrm{vf}$ & cs & Soft lime aggregates, common termites \\
\hline & $57-83$ & 10YR 3/2 & $\mathrm{C}$ & $1 \mathrm{abk}$ & $1 \mathrm{f}$ & Cs & Soft $\mathrm{CaCO}_{3}$, common krotovina \\
\hline & $83-111$ & 10YR 3/2 & $\mathrm{C}$ & ma & - & ws & Hard $\mathrm{CaCO}_{3}$ concretion and $\mathrm{CaSO}_{4}$ \\
\hline & $111-150$ & $10 Y R 3 / 2$ & $\mathrm{C}$ & ma & - & ws & Hard $\mathrm{CaCO}_{3} \mathrm{~S}$ concretion and $\mathrm{CaSO}_{4}$ \\
\hline
\end{tabular}

Texture $^{\text {a }}$ C: clay; Scl: sandy clay loam; Sic: silty clay; Cl: clay loamy; L: loam. Structure ${ }^{\mathbf{b}}$; 1: weak; 2: moderate; 3: strong; f: fine; m: medium; c: coarse; sbk: subangular blocky; abk, angular blocky; ma: massive. Rootsc; 1: very few; 2: few; 3; moderate; 4: common; f: fine; m: medium; c: coarse. Boundaryd; a: abrupt; c: clear; d: diffuse; i: irregular; s: smooth; w: wavy. 
Table 3. Some physical and chemical properties of the representative profiles.

\begin{tabular}{|c|c|c|c|c|c|c|c|c|c|c|c|c|}
\hline Profile No. & $\begin{array}{l}\text { Depth } \\
\text { cm }\end{array}$ & $\begin{array}{c}\text { Clay } \\
\%\end{array}$ & $\begin{array}{c}\text { Silt } \\
\%\end{array}$ & $\begin{array}{c}\text { Sand } \\
\%\end{array}$ & $\begin{array}{c}\text { Texture } \\
\text { Class }\end{array}$ & $\begin{array}{l}\mathrm{pH} \\
\text { Paste }\end{array}$ & $\begin{array}{c}\mathrm{E} \mathrm{C} \\
\mathrm{dSm}^{-1}\end{array}$ & $\begin{array}{c}\mathrm{P} \\
\mathrm{ppm}\end{array}$ & $\begin{array}{c}\text { O.M. } \\
\%\end{array}$ & $\begin{array}{c}\text { CEC } \\
\text { meq/100g }\end{array}$ & ESP & $\begin{array}{c}\mathrm{CaCO}_{3} \\
\%\end{array}$ \\
\hline \multirow{5}{*}{ P1 } & $0-18$ & 65.9 & 12 & 22.1 & Clay & 7.9 & 0.75 & 4.7 & 0.073 & 58.5 & 1.67 & 9.59 \\
\hline & $18-48$ & 63.1 & 11.5 & 25.4 & Clay & 7.97 & 0.7 & 5.7 & 0.056 & 56.1 & 8.05 & 8.82 \\
\hline & $48-80$ & 63.1 & 11.2 & 25.7 & Clay & 7.85 & 2.13 & 5.8 & 0.036 & 56.2 & 2.66 & 8.42 \\
\hline & 80 - 105 & 62.5 & 11 & 26.5 & Clay & 7.8 & 2.9 & 3.8 & 0.033 & 55.9 & 6.26 & 7.47 \\
\hline & $105-150$ & 65.1 & 10.8 & 24.1 & Clay & 7.9 & 1.75 & 4.6 & 0.031 & 57.8 & 10.17 & 13.46 \\
\hline \multirow{4}{*}{ P2 } & $0-30$ & 39.5 & 13.6 & 47 & $\begin{array}{l}\text { Sandy } \\
\text { Clay }\end{array}$ & 8.17 & 3.2 & 5.7 & 0.057 & 35.1 & 32.23 & 7.46 \\
\hline & $30-45$ & 49.1 & 12.8 & 38.1 & Clay & 8.27 & 22 & 5 & 0.038 & 43.7 & 35.05 & 6.42 \\
\hline & $45-107$ & 57.2 & 12.6 & 30.2 & Clay & 8.17 & 17 & 4.3 & 0.036 & 49.2 & 34.55 & 7.88 \\
\hline & $107-150$ & 57.2 & 12.1 & 30.7 & Clay & 8.4 & 8.5 & 5.6 & 0.034 & 49.3 & 38.42 & 8.31 \\
\hline \multirow{5}{*}{ P3 } & $0-27$ & 49.8 & 13.7 & 36.5 & Clay & 8.15 & 1.45 & 4.8 & 0.055 & 44.1 & 15.19 & 8.13 \\
\hline & $27-56$ & 51.5 & 13.5 & 35 & Clay & 8.3 & 1 & 6.3 & 0.043 & 45.5 & 20.1 & 7.93 \\
\hline & $56-84$ & 58.2 & 13.1 & 28.7 & Clay & 8.35 & 3.3 & 4.8 & 0.041 & 50.1 & 25.84 & 9.32 \\
\hline & $84-130$ & 63.3 & 12.9 & 23.8 & Clay & 8.11 & 6 & 4.7 & 0.036 & 55.2 & 24.76 & 5.47 \\
\hline & $130-150$ & 63.3 & 12.5 & 24.2 & Clay & 8.12 & 8.7 & 5.6 & 0.034 & 55.1 & 34.52 & 5.19 \\
\hline \multirow{6}{*}{ P4 } & $0-12$ & 54.4 & 14.6 & 31 & Clay & 7.51 & 1.8 & 7.6 & 0.076 & 47.8 & 3.49 & 4.41 \\
\hline & $12-48$ & 54.4 & 14.1 & 31.5 & Clay & 7.8 & 0.7 & 5.5 & 0.097 & 47.6 & 3.09 & 4.31 \\
\hline & $48-68$ & 26.3 & 14.1 & 59.6 & $\begin{array}{l}\text { Sandy } \\
\text { Clay }\end{array}$ & 8.12 & 0.4 & 4.7 & 0.095 & 23.1 & 3.2 & 5.2 \\
\hline & $68-86$ & 26.3 & 14 & 59.7 & $\begin{array}{l}\text { Sandy } \\
\text { Clay } \\
\text { Loam }\end{array}$ & 8.14 & 0.35 & 5.7 & 0.088 & 22.9 & 3.1 & 4.51 \\
\hline & $86-111$ & 26.3 & 14 & 59.7 & $\begin{array}{l}\text { Sandy } \\
\text { Clay } \\
\text { Loam }\end{array}$ & 8.1 & 0.35 & 5 & 0.069 & 23.1 & 3.03 & 3.99 \\
\hline & $111-150$ & 26.3 & 14 & 59.7 & $\begin{array}{l}\text { Sandy } \\
\text { Clay } \\
\text { Loam }\end{array}$ & 8.1 & 0.3 & 5.6 & 0.069 & 23.4 & 3.03 & 4.12 \\
\hline \multirow{6}{*}{ P5 } & $0-12$ & 51.1 & 11.9 & 37 & Clay & 8.1 & 1.4 & 4.1 & 0.074 & 6.21 & 45.8 & 29.96 \\
\hline & $12-36$ & 51.5 & 11.7 & 36.8 & Clay & 8.17 & 1.85 & 4.9 & 0.067 & 6.46 & 45.5 & 20.29 \\
\hline & $36-57$ & 51.2 & 11.5 & 37.3 & Clay & 7.97 & 3.4 & 5 & 0.059 & 7.05 & 45.3 & 16.69 \\
\hline & $57-83$ & 52.1 & 11.2 & 36.7 & Clay & 8.17 & 3 & 5.1 & 0.06 & 6.3 & 45.6 & 20.17 \\
\hline & $83-111$ & 54.4 & 11.1 & 34.5 & Clay & 8.07 & 4.9 & 5.1 & 0.053 & 5.89 & 45.1 & 28.76 \\
\hline & $111-150$ & 50.4 & 11.4 & 38.2 & Clay & 7.94 & 6.1 & 5 & 0.052 & 5.97 & 45.2 & 34.58 \\
\hline
\end{tabular}

$\mathrm{cm}$, slightly saline at the bottom depth $84-150 \mathrm{~cm}$, sodic and slightly calcareous. The Nile flood plain soil was non-saline, non-calcareous and non-sodic; it was very suitable for agriculture. The soil of Shambat area-College of Agricultural Studies Farm is non-saline at the top surface 0 - $83 \mathrm{~cm}$, and slightly saline at the bottom 83 $150 \mathrm{~cm}$, sodic and slightly calcareous soil. The soil $\mathrm{CaCO}_{3}$ content of the studied samples ranged from $3.99 \%$ to $28.76 \%$ in all studied locations.

\subsection{Estimation of Calcium Carbonate by Using Titration and Calcimeter Methods}

Table 4 shows the statistical analysis between the two methods. Results revealed that there are no significant differences between the two most in all studied locations, except in samples from Gedaref location which shows 
significant difference and recorded as (5.598 and 5.760) respectively. Carbonates mainly forms of, $\mathrm{Ca}^{++}$as $\left(\mathrm{CaCO}_{3}\right), \mathrm{Mg}^{++}\left(\mathrm{MgCO}_{3}\right)$ magnetite, $\mathrm{Na}^{+}\left(\mathrm{NaCO}_{3}\right) \mathrm{Fe}^{++}\left(\mathrm{FeCO}_{3}\right)$. Carbonates were deposited by sedimentation in marine or Lake Environment. Carbonates can also originate within organic materials resulting from living organisms (Products resulting from the degradation of limestone rocks through erosion), $\mathrm{pH}$ measurements between approximately 7.5 and 8.5 indicate the presence of carbonates. A higher $\mathrm{pH}$ (Towards 10) can indicate the presence of sodium carbonate [17] (Janitz, 1986).

Readings observed from titration method were higher than that of calcimeter method (Figure 1). Although, there were no significant difference between the calcimetric and titrimetric methods, except in the case of (Eldaim Fruits and vegetables Farm-Gedaref area) and that probably due to addition of $\mathrm{HCl}$ to the soil in titration method, which lead to ferrous and aluminum oxide displacement, and later precipitation in form of hydroxides when the titration done by sodium hydroxide.

$$
\begin{gathered}
6 \mathrm{HCl}+\mathrm{Fe}_{2} \mathrm{O}_{3} \rightarrow 2 \mathrm{FeCl}_{3}+3 \mathrm{H}_{2} \mathrm{O} \\
6 \mathrm{HCl}+\mathrm{Al}_{2} \mathrm{O}_{3} \rightarrow 2 \mathrm{AlCl}_{3}+3 \mathrm{H}_{2} \mathrm{O} \\
\mathrm{FeCl}_{3}+3 \mathrm{NaOH} \rightarrow \mathrm{Fe}(\mathrm{OH})_{3}+3 \mathrm{NaCl} \\
\mathrm{Al}_{2} \mathrm{Cl}_{3}+3 \mathrm{NaOH} \rightarrow \mathrm{Al}(\mathrm{OH})_{3}+3 \mathrm{NaCl}
\end{gathered}
$$

The enough consumed acid to dissolve oxides was equal to $\mathrm{NaOH}$ precipitating hydroxides. So the estimation of calcium carbonate by calcimeter was not affected, but some of the acid also lost by; reaction with exchangeable calcium and magnesium ions at clay surface, or reaction with other clay minerals. As the soil of Gedaref area is heavy clay, this explained the result of significant difference when the two methods were used. In general; to avoid that error, it is better to put in mind the several advantages of calcimeter method than that of titration method.

Table 4. Statistical comparison between titration method and calcimeter method results.

\begin{tabular}{ccc}
\hline Profile No. & Tabulated T-value & Calculated T-value \\
\hline P1 & 5.598 & $5.760^{*}$ \\
P2 & 7.453 & $4.846^{\text {N.S }}$ \\
P3 & 5.598 & $3.525^{\text {N.S }}$ \\
P4 & 4.773 & $2.440^{\text {N.S }}$ \\
P5 & 4.773 & $4.335^{\text {N.S }}$ \\
\hline
\end{tabular}

\footnotetext{
N.S $=$ Non - Significant at $\mathrm{P}<0.05,{ }^{*}=$ Significant.
}

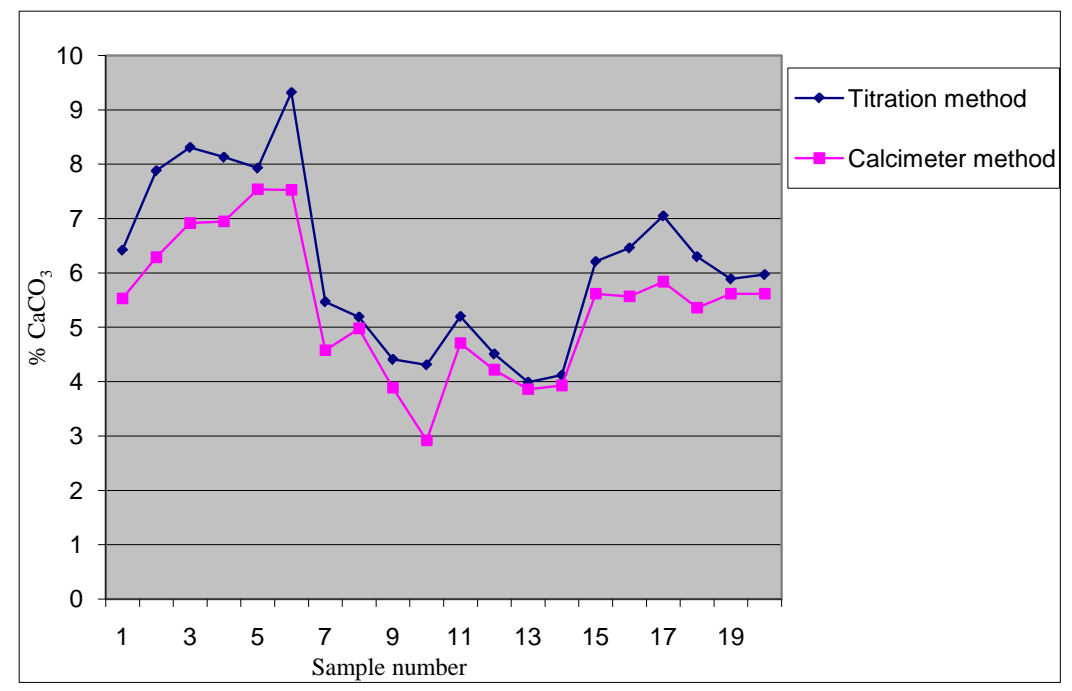

Figure 1. Comparison between titration method and calcimeter method. 
[18] Maulood et al., (2012) studied the comparison between the titrimetric and calcimetric for $\mathrm{CaCO}_{3}$ determination in 84 different locations of soils from Iraq. They obtained no significant differences between the two methods and the two method were highly correlated ( $r=0.993$ to 0.998). In contrast, [19] Kassim (2013) mentioned that, the results of calcium carbonate equivalent estimated by Calcimeter were lowest as compared to acid neutralization and acetic acid methods. [4] El Mahi et al., (1987) reported that the values of carbonate equivalent estimated by acid neutralization were corrected as:

$\mathrm{CaCO}_{3}$ equivalent $=$ acid neutralization $\% \mathrm{CaCO}_{3}-0.05$ CEC .

\section{Conclusion}

After comparing calcimeter method with titration method, we conclude that there are many advantages when using calcimeter method, such as: no other chemicals are needed, no long waiting periods, no very accurate weighing equipment is needed, accurate and suitable for our Sudanese soils. Therefore, it is recommended to use this method because titration method is slow and labour intensive. In addition to that, there is no significant difference between it and titration method in most soil types in Sudan.

\section{Acknowledgements}

Special thanks to the staff of the laboratories of the Land and Water Research Centre at the Agricultural Research Corporation, Wad Medani, and the Staff of Soil Science and Water Department at College of Agricultural Studies, Sudan University of Science and Technology, for availing their laboratories facilities and for their technical advice.

\section{References}

[1] Elfaki, J.T., Gaver, M. and Magboul, M.S. (2015) Comparison and Evaluation of Two Analytical Methods for Cation Exchange Capacity and Exchangeable Sodium Percentage of Five Soil Types in Central Sudan. Open Journal of Soil Sciences, 5, 311-318. http://dx.doi.org/10.4236/ojss.2015.512029

[2] Ibrahim, S.I. (2008) Soils of the Arid and Semi-Arid Regions. UNESCO, Uni. Of Khartoum, Kahrtoum, 227.

[3] Shepherd, K.D. and Walsh, M.G. (2002) Development of Reflectance Spectral Libraries for Characterization of Soil Properties. Soil Science Society of America Journal, 66, 988-998. http://dx.doi.org/10.2136/sssaj2002.9880

[4] El Mahi, Y., Ibrahim, I.S., Abdel-Majid, H.M. and Eltilib, A.M. (1987) A Simple Method for Determination of Calcium and Magnesium Carbonate in Soils. Soil Science Society of America Journal, 51, 1152-1155. http://dx.doi.org/10.2136/sssaj1987.03615995005100050010x

[5] Rowell, D.L. (1994) Soil Science: Methods and Applications. Prentice Hall, Harlow.

[6] Loeppert, R.H. and Suarez, D.L. (1996) Carbonate. In: Sparks, D.L., et al., Eds., Methods of Soil Analysis. Part 3. Chemical Methods, ASA and SSSA, Madison, 437-474.

[7] Hodgson, J.M. (1974) Soil Survey Field Handbook. Technical Monograph No. 5. Soil Survey of England and Wales, Harpenden.

[8] Horváth, B., Opara-Nadi, O. and Beese, F. (2005) A Simple Method for Measuring the Carbonate Content of Soils. Soil Science Society of America Journal, 69, 1066-1068. http://dx.doi.org/10.2136/sssaj2004.0010

[9] Food and Agricultural Organization (2006) Report on the Ad Hoc Expert Consultation on Land Evaluation, World Soil Resources. Report 45. FAO, Rome, $152 \mathrm{p}$.

[10] Soil Survey Staff (2014a) Keys to Soil Taxonomy. A Basic System of Soil Classification for Making and Interpreting Soil Surveys. 2nd Edition, Agric. Hand Book No. 436, USDA, Washington DC.

[11] Blakemore, L.C., Searle, P.L. and Daly, B.K. (1987) Methods for Chemical Analysis of Soils. New Zealand Soil Bureau Scientific Report 80.

[12] Mario, P. and Rhoades, J.D. (1977) Determining Cation Exchange Capacity: A New Procedure for Calcareous and Gypsiferous Soils. Soil Science Society of America Journal, 41, 524-528. http://dx.doi.org/10.2136/sssaj1977.03615995004100030018x

[13] Chapman, H.D. (1965) Cation-Exchange Capacity. Agronomy, 9, 891-901.

[14] Soil Survey Staff (2014b) Kellogg Soil Survey Laboratory Methods Manual. In: Burt, R., Soil Survey Staff, Eds., Soil Survey Investigations Report No. 42, Version 5.0, U.S. Department of Agriculture, Natural Resources Conservation Service. 
[15] Olsen, S.R. and Sommers, L.E. (1982) Phosphorus. In: Page, A.L. and Miller, R.H., Eds., Methods of Soil Analysis, Part 2, 2nd Edition, Agronomy Monograph 9, ASA and SSSA, Madison, 403-430.

[16] Sendecor, G.W. (1965) Statistical Methods. Lowa State University Press, Ames.

[17] Janitz, K.L. (1986) Soil Particle Size Analysis. U.S. GOV., Print Office. Washington DC.

[18] Maulood, P.M., Esmail, A.O., Dohuki, M.S.S. and Dalshad, A.D. (2012) Comparison between Calcimetric and Titrimetric Methods for Calcium Carbonate Determination. Open Journal of Soil Science, 2, 263-268. http://dx.doi.org/10.4236/ojss.2012.23031

[19] Jabbar, K.K. (2013) Method for Estimation of Calcium Carbonate in Soils from Iraq. International Journal of Environment, 1, 9-19. 